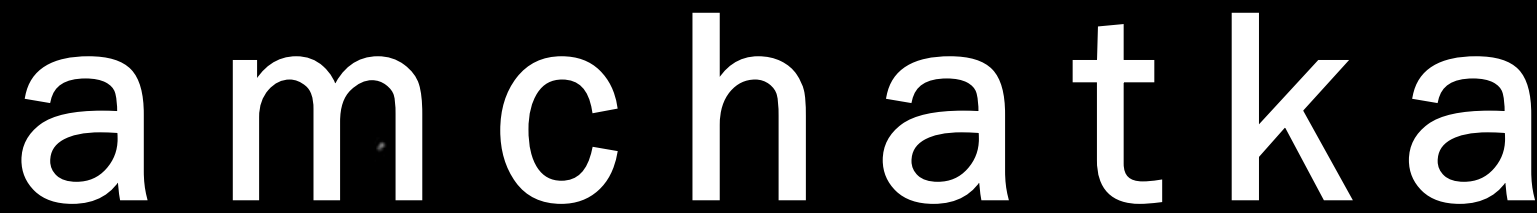

Revista de análisis cultural

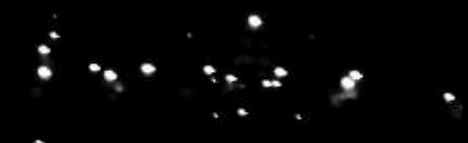

N. 16
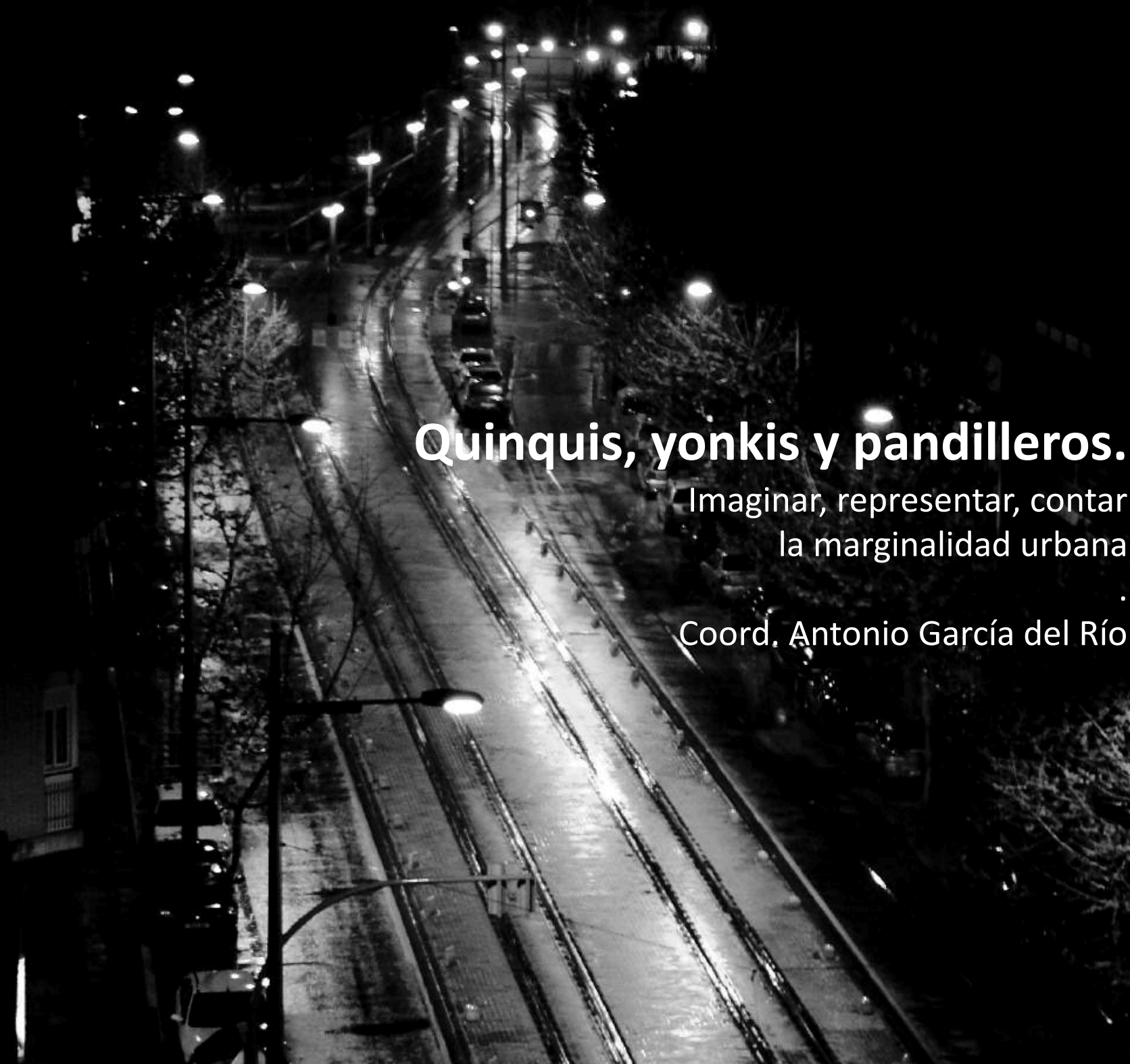

Fmaginar, representar, contar

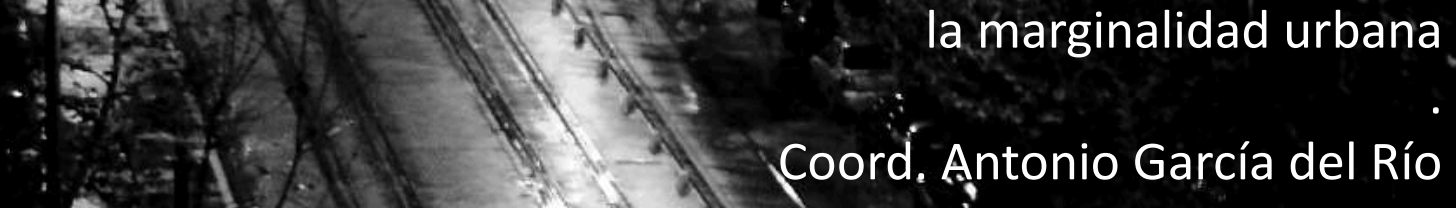

$\frac{1}{2}$

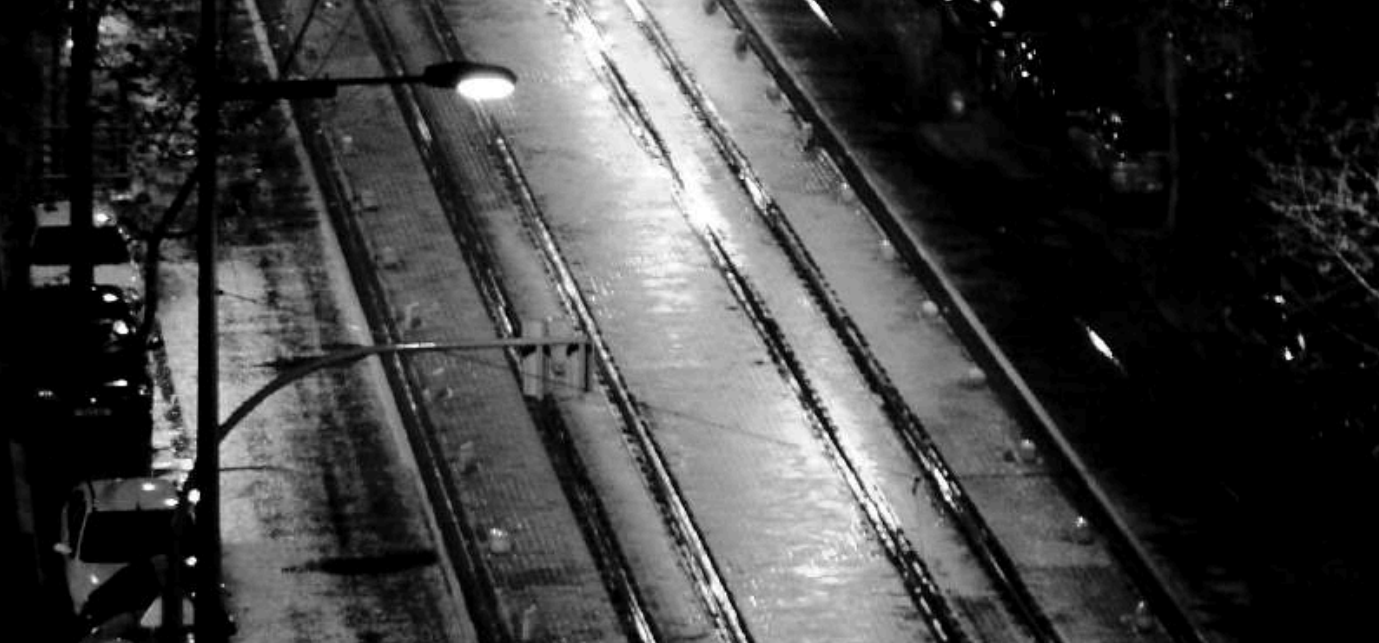




\title{
QUINQUIS, YONKIS Y PANDILLEROS. IMAGINAR, REPRESENTAR, CONTAR LA MARGINALIDAD URBANA
}

\author{
KAMCHATKA. REVISTA DE ANÁLISIS CULTURAL 16 (2020)
}

Monográfico coordinado por ANTONIO GARCíA DEL RíO

ANTONIO GARCía DEL RíO. Quinquis, yonkis y pandilleros. Imaginar, representar, contar la marginalidad urbana.

I. MUNDOS, MITOS E HISTORIAS QUINQUIS

GERMÁN LABRAdOR MÉNDEZ. El mito quinqui. Memoria y represión de las culturas juveniles en la transición postfranquista.

Paula PÉrez-Rodríguez. Historia conceptual del quinqui. Pluriempleo, policía, prensa y mito.

SOFÍA NiCOLÁS DíAZ. Sobre rap, trap y calle: imágenes y fenómenos.

ANTONIO GARCía DEL Río. De vagos y maleantes, bandidos y censores: la contraimagen del quinqui durante el franquismo en obras de Rodríguez Méndez.

\section{CONTEXTOS PARA UNA NUEVA HISTORIA CULTURAL}

ANTONIO ORIHUELA. ¡Más chutes no! La heroína, entre arma de la democracia y vehículo heroico.

Carmen Medina Puerta. "Construir la poesía como una enfermedad de la piel": la representación del VIH/SIDA en la España democrática.

Alejandro Civantos URrutia. ¡Quita esa gorra de obrero! Desproletarización editorial en la Transición española. 
III. OTRAS MARGINALIDADES EN CONTEXTOS LATINOAMERICANOS

Mariel Bufarini. Percibir y resistir los estigmas. Un estudio sobre la cotidianeidad de personas en situación de calle.

Juan Fernando Pavez Pérez, María josé Reyes Andreani, Francisco Jeanneret, maría Angélica Cruz, César Castillo, Juan Jeanneret, Manuela Badilla, CENTRO DE INTERPRETACIÓN FiSURA FISURA. Murales y políticas de memoria en un "barrio crítico" de Santiago de Chile.

AneXo Al MONOgRÁfico. TEXTos De homenaje.

Resistir a les palpentes / Resistir a tientas. Poemas de Antonio García del Río.

SEMBLANZA DE TONY Y CUADERNO DE VOCES.

Imagen de portada: fotografía de Antonio García del Río. 
CUADERNO DE VOCES PARA TONY 
TONY, tu llegada a nosotros fue tardía pero recibida con infinita ilusión.

La evolución de tu vida, fue sin duda lo mejor para nosotros.

Fuiste: excelente hijo, hermano, tío, nieto, sobrino, primo.

Siempre: cariñoso, risueño, compañero, amigo, leal, competente, transparente.

Pero la fatalidad, ha truncado demasiado pronto tú trayectoria, alejándote de nuestro lado.

Tenías muchas inquietudes, ilusiones y perspectivas, algunas han quedado y seguirán plasmadas y otras muchas se fueron contigo, no dudando que allí en donde estés, las puedas desarrollar y sean disfrutadas por aquellos ángeles que estén a tu lado.

Solo decirte que, para nosotros, iiTONY!! siempre perdurará:

“EL TEU SOMRIURE I LA TEUA LLUM, SEMPRE AMB NOSALTRES, NO T’OBLIDAREM MAI”.

ELS TEUS PARES 
TONY, recordamos como si fuera ahora, cuando nuestros padres nos dijeron que íbamos a tener un hermano, no podíamos parar de sonreír y saltar de alegría y emoción.

Recordamos cuando todos juntos fuimos a conocerte en tu primera ecografía.

Recordamos el día que naciste, llovía a cántaros, una larga espera, llena de nervios y emoción invadía la sala en la que esperábamos y por fin llegaste a este mundo, tú, tan guapo, moreno, redondito...

Recordamos tú llegada a casa, salimos corriendo del colegio y al llegar, ahí estabas tú, no podíamos dejar de mirarte.

Hacíamos turnos mientras dormías para cuidarte, creíamos que siempre te podríamos cuidar y proteger, pero no ha podido ser.

Ahora sabemos que el que nos protegerá serás tú, allá donde estés .

Eres nuestro ejemplo a seguir.

“PER SEMPRE T’ESTIMEM”.

ELS TEUS GERMANS: DAVID I NATALIA. 


\section{TONY:}

Recordamos muchos momentos contigo, tantos que no sabríamos por donde empezar.

Por ejemplo, cuando llegábamos del colegio a casa de los yayos los viernes, tú siempre nos preguntabas como nos había ido el día, qué habíamos hecho en clase, si habíamos hecho algún examen, como nos había salido, etc..

Eras como un libro abierto, siempre nos explicabas miles de cosas sobre escritores, cantantes...

Hacías que aprender fuera divertido, podíamos pasar horas y horas escuchándote, escuchando todo lo que sabías. Una de las cosas de las que más nos gustaba hablar contigo, era sobre la música, nos has enseñado miles de canciones y miles de géneros distintos.

Gracias a ti nos hemos leído muchos libros y has hecho que nos guste leer.

Otro recuerdo muy divertido fue cuando en un cumpleaños Silvia y Aitana estaban bailando escuchando música y apareciste por la puerta y nos empezamos a reír los tres.

Te lo pasabas muy bien jugando con Ivet y con Carlos, un recuerdo muy especial para ellos fue cuando Carlos e Ivet fueron al cine contigo y con Teresa, ellos no se querían ir de allí, querían quedarse a dormir con vosotros y estar jugando horas y horas.

Tiet Toni, moltes gràcies per ajudar-nos i perquè has sigut i seràs el nostre exemple a seguir.

T'ESTIMEM MOLT, ADÉU, FINS SEMPRE.

ELS TEUS NEBOTS PREFERITS.

Aitana, Silvia, Ivet i Carlos. 
Ojalá poder escribirte y que me contestes con un «hola boleta», llamarte y escuchar tu voz al otro lado del teléfono.

Ojalá poder ir corriendo a casa y abrazarte, tumbarnos en el sofá y enrollarnos entre mantas. Cantar juntos Quique González y volver a pasear abrazados por el Puente de las Flores o de Serranos. Perdernos por el Carmen, recordar los primeros besos y hacernos fotos.

Encontrar una notita entre mis libros que ponga «te quiero». Pedirte un libro y estar horas hablando. Ojalá pasar un domingo sin hacer nada, pero todo el rato juntos, escuchando música. Querer ver una película y enfadarte, porque a los cinco minutos me había dormido.

Ojalá volver a saltar en un concierto, empujarnos y luego reír cuando la cerveza se caía al suelo. Hacernos treinta fotos y que me digas que en todas llevas mal el pelo.

Ojalá despertarme y que estés a mi lado diciéndome que recién levantada estoy muy guapa. Salir a desayunar, a comprar libros y de vuelta a casa comprar una planta porque querías tener el balcón más bonito de Jorge Juan.

Ojalá poder verte, aunque fuera solo un minuto y poder decirte que por aquí te echamos de menos y que ahora todos somos un poco tú.

Me gustaría poder decirte que desde que te has ido no paramos de recordar tus anécdotas, que reímos juntos y que siempre sale un «si Tony estuviera».

Que cuando brindamos sé que pensamos «y esta por Tony», pero todavía nadie se atreve a decirlo. Me gustaría decirte que estamos aprendiendo a vivir de tus recuerdos, de tu música, de tus poemas, de tantas cosas que has dejado.

Sé que desde ahí arriba nos estás viendo y cuidando, así que sigue.

Riéndote con nosotros y de nosotros.

En el bolsillo de tu camisa a cuadros te escribí el último día que tu eterno amor y ganas de vivir serían mi consuelo.

Siempre serás mi chico favorito. Siempre.

TERESA DONDERIS 


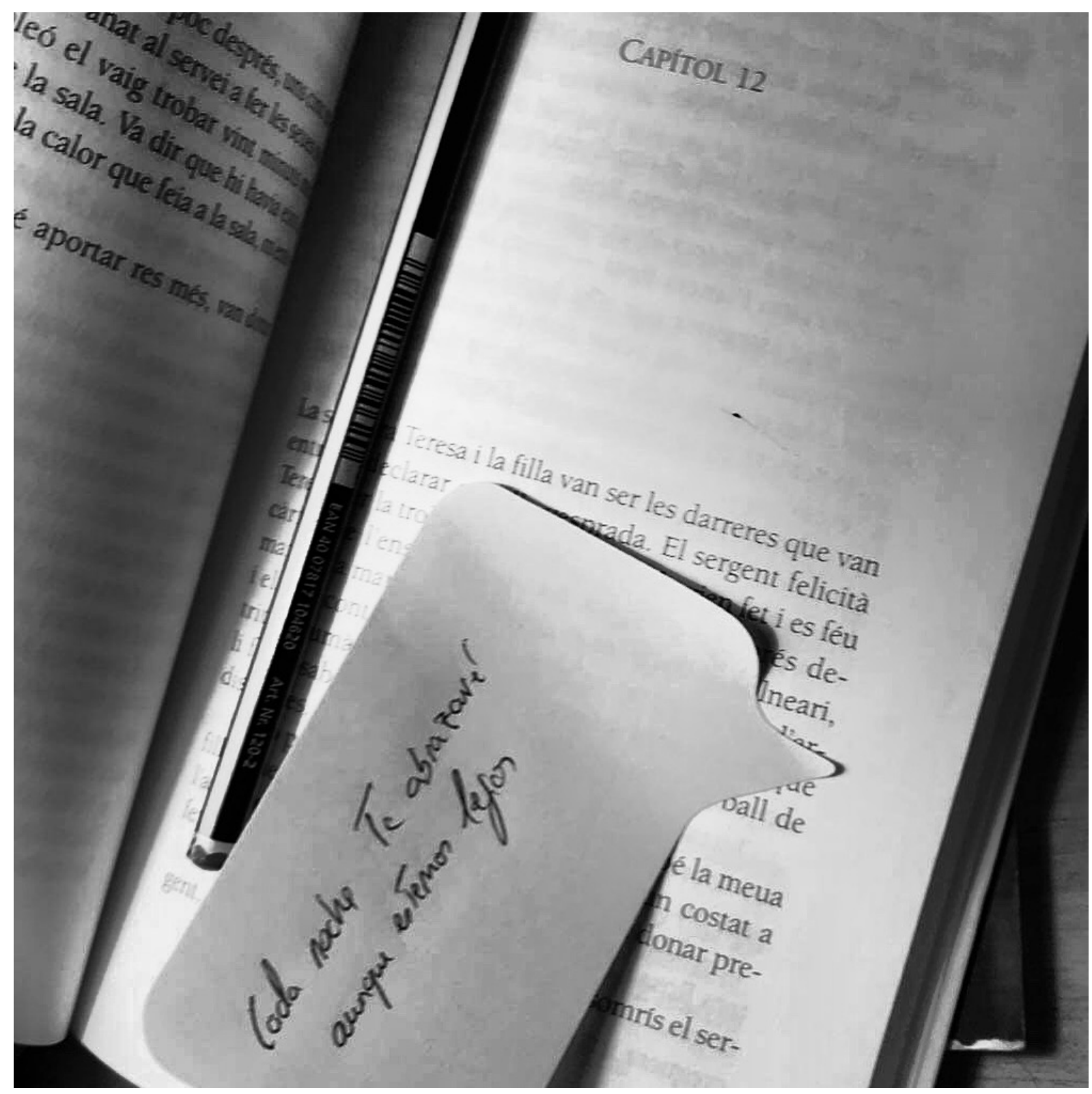


1 de julio, 11.26 a.m.

"Camarada!!!! Ayer me dijo un pajarito que la tesis va por buen camino, buenísimos!!! Me alegro muchísimo de verdad!!! Dejando el pabellón bien alto!!!! :D :D :D :D :D será la hostia!!"

Leo Simón

la última novela de Miqui Otero

habla de un niño catalán del extrarradio

pura clase obrera

que se cría en el bar Baraja

entre fritos y taxistas

Cojo el móvil para escribirte:

"Vas a alucinar, este tío parece

una versión renovada de Marsé",

después recuerdo

que hace dos días exactamente

estuvimos llorándote

en un tanatorio apartado

en el polígono que hay junto a mi barrio

Así

desarmada

subo con el dedo por la conversación

y leo uno de tus mensajes

previo al periodo de hospital

mandando amor y buenos deseos

para una tesis doctoral

que terminé en cuarentena

Entonces pienso

en las cosas inacabadas que dejas por aquí

en todo lo que tu marcha interrumpe

en la pasión que le ponías a unos proyectos

que se frenan de golpe

como los coches tuneados de los quinquis

quemando rueda

con el freno de mano temblando

la revista

los poemas 
las clases

y esa investigación

sobre los chicos que poblaron las periferias

y perdieron el rumbo entre mentiras

drogas

operaciones policiales

orquestadas por un Estado clasista y asesino

la revista

los poemas

las clases

tu vida con Tere

los niños que no vinieron

pero a los que todos poníamos ya cara

$\mathrm{y}$ gestos y nombres

No sé cómo hablar de todo lo que no ha sucedido solo sé que nombrarlo

nos permite tenerlo presente

y recoger de alguna forma

los pedazos de vida que dejaste

la ilusión incontrolable

y esos buenos deseos

que están contigo ahora

en el pabellón más alto del mundo

ÁNGELA MARTíNEZ FERNÁNDEZ 
Aquest poema va ser escrit el dia cinc d'octubre de 2020, tan sols tres dies després que ens acomiadéssim de tu. Encara no sé com vaig poder nomenar tot el que havia passat. En aquell moment, escriure't em va servir per a congregar-te i mantenir-te a prop. Ara, l'escriptura és l'única cosa que em permet fer que tornes i minore aquest dolor tan gran que tot ho paralitza. Des que no estàs ja ningú és el mateix, l'única cosa que roman indemne és el desig que tenim de fer de tu un record constant, en la Facultat, en els carrers, en els bars, que tot s'òmpliga de tu per a sostindre't ací. Jo ho intente en la nostra llengua, fent casa de la paraula i refugi comú, com tu ens vas ensenyar.

T'estimem, amic, t'estimem d'una forma que no hi cal explicar.

«I les paraules no brollen,

s'enquisten abans de nàixer».

Això no és cap cosa a retraure,

però t'ho volia dir, amic.

Que «el so s'ha diluiit des que no el fas sortir»

Que tot ha perdut solidesa i s'esvaeix

encara que fem per riure i llepar-nos les ferides les unes a les altres.

Perquè ens cal això,

un farcell d'afectes i tendreses que ens sostinga,

clavar-li dentegada al record dolç

i no deixar-lo anar mai.

Perquè ens cal a totes i cadascuna

pensar-te «amb la camisa descordada i desenes d'amulets al pit obert»,

omplint de llum aquest camí esquerdat.

Perquè, buides, quant ens cals.

Haurem de resistir i haurem de fer-ho «a les palpentes»,

sense cap dignitat ni orgull,

ara que assimilem que no hi vindràs

i que només tu seràs qui dirà

«quan i com».

NÚRIA LORENTE. 
El 25 de septiembre de 2020, exactamente una semana antes de que Tony muriera, le escribí los que serían los últimos mensajes de nuestra conversación telemática. Un día más, me había despertado profundamente conmovida por un sueño tan vívido que me costaba aceptar que no hubiera sido real, y sentí la necesidad de hacérselo saber. En ese sueño, Tony y yo paseábamos cerca de la playa, cogidos de la mano, celebrando que estaba lo suficientemente fuerte como para haber salido del hospital y cuando él comentaba su proeza entre risas, yo le daba un abrazo muy fuerte, dejándome una sensación de placidez y plenitud que no recuerdo haber sentido en ningún otro momento de mi vida. La impotencia acumulada por no poder acompañar $y$ disfrutar de mi amigo durante los meses anteriores me llevó a fantasear con la idea de que los sueños fueran un territorio legítimo de reencuentro, en el que el Tony soñado no fuera una creación de mi subconsciente sino el vector de su verdadera conciencia, y que ambos compartiéramos el mismo sueño desde camas situadas en lados opuestos de la ciudad.

Tony nos ha faltado pero yo he seguido encontrándome con él muchas noches, así que he decidido buscar otra explicación. Existe una hipótesis en la física cuántica que defiende la posibilidad de que existan múltiples universos o mundos paralelos, surgidos del desdoblamiento de una realidad ante un evento concreto. Pienso en una dimensión paralela a la nuestra en la que Tony se ha curado, o ni siquiera ha enfermado, en la que nuestras vidas no se han fracturado por el dolor de su pérdida, y hemos seguido compartiendo un camino de conversaciones profundas, viajes colectivos, lecturas estimulantes, anécdotas bochornosas y muchas carcajadas; en fin, madurando todos juntos sin ser conscientes del privilegio que ha sido tenerlo cerca. Pienso en la posibilidad de que los sueños sean una interferencia de esos mundos con mi universo, una ventana que me permite constatar que hay un Tony en algún lugar pasando un buen rato con una de mis yoes. Así que decido poner mi fe al servicio de la física teórica y disfrutar de mis encuentros oníricos con los Tonys del multiverso.

MARTina PÉREZ MARTÍNEZ-BARONA 


\section{DANCING IN THE DARK}

Ayer soñé con él. Suele pasarme, cuando alguien marcha para siempre, que a las pocas semanas se convierte en protagonista de algún sueño. Es el momento, me digo, en que parece que comienzo a comprender. Es el fin de un proceso: la primera ola, el primer gran golpe en la boca del estómago. Y el inicio de otro. Podría pararme a pensar en qué me dijo, pero no conseguiría dejar nada en claro. Imagino, sin embargo, que hablaríamos de lo nuestro: de los libros, las canciones, las películas, los barrios. Él era de uno de ellos, esos lugares un tanto inhóspitos, repletos de edificios con toldos verdes en las fachadas y algunos bajos comerciales que, de tanto en tanto, echaban el cierre. Yo vengo de otras geografías, algo más alejadas y de ambiente menos cargado, donde según nos dicen disfrutamos del aire puro, aunque él sabía, como yo, que esto no es más que un trampantojo que esconde, al cabo, el sudor diario por la subsistencia. Quizás en eso nos parecíamos, aunque nunca se lo dije. Nos unía, también, la sonrisa, o eso cuentan. No sé lo que pasó en aquel sueño, pero imagino que Tony reiría y que yo también lo hice recordando alguna que otra historia común o ajena, quién sabe. Todavía hoy, varios meses después, puedo escuchar el tono de su voz en los recodos. I get up in the evening, and I ain't got nothing to say, decía el maestro, ¿’O acaso no es cierto, amigo?

RAÚl MOLINA GIL 
Tony siempre describía el tono emocional de una amistad a través de las referencias compartidas. Si hubiera tenido que elegir una para definir la nuestra creo que hubiera dicho, sin titubear, que a los dos nos encantaba Nebraska. Fue siempre una amistad desnuda, sin ornamentos, echa de materiales básicos y basada en una complicidad profunda. Un espacio de confianza en el que nada podía fallar. Una hermosísima rareza.

Su mundo estaba puntuado por canciones, novelas y películas, con las que comparaba las experiencias que vivía y les daba forma y valor. Una calle de Zaidía podía albergar una escena de Scorsese o un diálogo de Marsé pero siempre había una textura compartida que Tony sabía descifrar. Era, además, su forma de tejer complicidades: encontrando en personajes, escenas y canciones la zona emocional que podía conectarle con quien tenía enfrente, fuera quien fuera; era un experto en hallar vínculos allí donde los demás no los podíamos ni imaginar. Ello explica su pasión por acumular detalles culturales, que era su forma particular de anticipar afectos nuevos.

Su humor partía también de ahí, trazando relaciones deformadas entre su vida y los referentes culturales que amaba, y que conocía mejor que nadie. Era guapísimo, inteligente y carismático, irradiaba luz. Pero se presentaba como una versión paródica de sí mismo, trazada con referencias irónicas que iban de la literatura picaresca a la televisión basura; en ellas, siempre encontraba la forma de reírse de sí mismo y de dejar su figura a la altura del betún. Era brillante en eso: difamándose, nos seducía a todos.

En los momentos más duros de su enfermedad encontró en ese humor una forma de hablarnos de aquello que no podía contar de otro modo: se comparaba con Rocky aguantando los golpes sin llegar a caer a la lona, pero también con Maradona desvaneciéndose a mitad de partido. Se trataba, sin duda, de una forma de cuidarnos, de brindarnos un tono con el que hablar de su enfermedad evitando dramatismos. Y también de indicarnos que seguía ahí, a pesar de todo. En sus últimos mensajes, confrontó nuestra angustia por las terribles noticias y la imposibilidad de visitarlo refiriéndose al hospital como su "hotel de pulserita y barra libre". Reímos con él mientras pudo seguir escribiendo.

La muerte de Tony ha dejado un vacío y un dolor que no sabemos cómo nombrar. Contarnos de nuevo sus anécdotas, escribir escenas de su vida, leer y comentar sus poemas... son las formas que vamos inventando para seguir escuchándolo y continuar teniéndolo cerca. Aun en ausencia Tony sigue uniéndonos, que es lo que siempre hizo mientras vivió. Lo hacía como si nada, con esa risa de apariencia infantil, pero su forma de estar en el mundo era también una apuesta política, un modo de construir vínculos y nuevas formas de comunidad en un espacio social que había arrasado con ellas. 
Tony amaba el cine negro y su vida estaba hecha, como el halcón maltés, del material con que se hacen los sueños. Quiero creer que algo de la intensidad y la pasión con que vivió ha quedado prendido en aquellos que estuvimos a su lado y que algunos de los sueños y proyectos que no pudo llegar a cumplir nos quedan, de un modo secreto, encomendados. Tony fue luminoso en vida. Y lo seguirá siendo en este tiempo que nos toca vivir sin él pero en el que, no tengo duda, encontrará la forma de acompañarnos de un modo nuevo.

JAUMe PERIS BLANES 
El rock'n'roll era l'excusa perfecta per a veure'ns cada vegada que jo anava a València de concert. Des d'aquell primer de Bruce a Madrid del 2007 anàrem a molts junts. I entre cançó i cançó parlàvem de la vida, dels teus estudis mentre curraves en assegurançes, de la novieta que et molaba molt. Parlàvem de muixeranga, de CCOO, del València i del Espanyol, de punk, de cine quinqui i del Víbora. De que escrivies per a una revista cultureta o de que te n'anaves becat a New Jersey.

La veritat tio, que amb tu era fácil parlar de tot. No se si vas aprendre alguna cosa de mi, jo de tu sí. Que l'amistat no és qüestió d'edat. I quina putada es escriure açó en passat.Ja et trobe a faltar Toni, un plaer amic!

"Meet you brothers and sisters on the other side, I'll see you in my dreams" (Bruce Springsteen). 
Vaig conéixer Toni de la mà de Lluis Saporta; ens férem amics i còmplices de seguida.

Sóc incapaç (i no tinc cap necessitat d'aclarir-ho ara) de saber el paper que va jugar la tremenda fascinació que em va produïr (no és fàcil trobar-te amb una combinació tan punyent de serenitat i de ganes, d'entusiasme, de criteri... i més) o la consideració que mostrava per mi i per algunes de les meues referències vitals $\mathrm{i}$ artístiques alhora, amb Óscar Briz, Juan Carlos Masià o Julio Galcerà al davant, a l'hora d'establir un vincle magnífic i ben productiu.

Parle de vida real, comptada en minuts; seria criminal, parlant de Toni, el recurs a llocs comuns o a frases fetes.

Ja no trobaré Toni en la peripècia (ni la trivialitat) quotidiana, però me'l trobaré sempre a la solemnitat de la memòria, a la vora d'un grapat (injusta i inacceptablement gran) de persones estimades que han fet $i$ fan que la vida siga alguna cosa més que un accident $i$ la humanitat, alguna cosa més que una espècie.

No te n'has anat, Toni; només has canviat de casa.

ENRIC CASSASSUS 
Compromès: amb si mateix, amb els altres, amb el seu entorn. Amb la seua cultura, la seua llengua. Obert, alegre, solidari, generós. Sempre amb la capacitat de trobar una paraula amable, un gest còmplice. D'escoltar, senzillament, quan cal, que és moltes vegades. Capaç de generar al seu voltant un espai de confiança, la clau de tot. Disciplinat en l'aprenentatge, en l'assistència, en els horaris, en la pròpia preparació física. Disposat a preguntar amb precisió de cirurgià per cada posició de les mans, dels braços, del cos, fins a assolir la seguretat plena. Valent. Humil. Una persona que sap entendre que les seues capacitats es posen al servei del col lectiu, sense el qual res no tindria sentit. Una persona, per tant, que sap fruir de les fites i les alegries col lectives, les veritablement importants.

Aquestes són, al meu parer, les virtuts d'un bon muixeranguer. No he trobat millor manera de descriure la impressió que em va causar Tony com a company de colla, com a persona. Ell les aplegava totes i, de segur, unes quantes més. No només això; les conreava cada dia en els assajos i les actuacions, amb la seua presència convençuda.

Vam tindre el privilegi de compartir una experiència tan especial com la muixeranga amb una persona excepcional. Però el temps li va ser arrabassat, de manera cruel. I precisament temps era el que necessitàvem, per conèixer-lo millor, en plenitud.

La seua pèrdua ens ha produït un enorme impacte, ens ha deixat un buit en la pinya. Així que li retrem homenatge fent allò que compartíem, muixeranga. Farem un acte anual en la seua memòria. S'ho deguem a Tony i al seu somriure franc, del qual s'aprenia més que de qualsevol acadèmia.

PAu Pertegaz (Jove MuiXeranga de VALĖNCIA) 
Quin record més bo!!! Va ser un dia guai.

Revise les nostres converses que han quedat escrites. Al messenger eixes són les teues darreres paraules. Responies a un xicotet vídeo que havia trobat de quan concidírem a la Trobada d'Escoles en Valencià, jo amb la meua filla, tu amb la Jove Muixeranga de València. Jo et vaig respondre amb un coret. Ja estaves a l'hospital.

Saps, Tony? Sempre et recorde amb un somriure. A la porta de la facultat, amb la teua xupa negra, fumant quan jo passava corrent per donar classe als americans i em saludaves amb la mà (cada matí continue veient, precís, al lloc exacte, el buit que has deixat), aquell dia a Benimaclet, o en altres nits anteriors de cerveses i poesia líquida. Ara tot és fa evident: la teua saviesa, la teua maduresa, la teua sensibilitat, el detall precís que nomenaves als versos, als posts, les cançons que evocaves, la genalogia de textos que construies, com si res, com si això fos fàcil. Així era la teua manera senzilla de ser genial. I profund. I conscient. I bo.

Et recorde amb un somriure concret en una retrobada, amb sornegueria suau. Hi hagué molts però aquell va ser un dels que em van fer sentir que el meu antic estudiant s'havia convertit en un amic estimat, dels que comprenen, dels que tenen el somriure just i la paraula oportuna. Ara tot és massa evident i fa mal, quan sent que la teua vida ha passat per les nostres fugaç com una llum fugissera i intensa, "como automóviles que pasaban rápidos por la carretera", i que ara que no està és més nítida que mai la claror que ens vas dur i fan mal les ocasions perdudes de passar més temps amb tu i les converses que no hem tingut.

A mi també em passa que m'han quedat moltes coses per contar-te, moltes cerveses per prendre'm amb tu, moltes coses que celebrar junts. Hauré de conformar-me amb la sort immensa d'haver-te conegut.

Quins records més bons, Tony!!! Qualsevol d'aquells va ser un dia guai.

JESÚs PERIS LLORCA 
Resulta difícil pensar en Tony sin la huella imborrable de su sonrisa. Una sonrisa tímida, pero profundamente luminosa y franca, que resultaba reveladora de su aguda curiosidad, de su arrolladora fuerza vital, de su cautivador carisma, de su extraordinaria empatía y sensibilidad.

Además, para mí, resulta difícil pensar en Tony sin la huella de su palabra. Esa que se expandía por el despacho durante las largas tardes de invierno cuando, por momentos, dejando de lado las lecturas de nuestros trabajos, nos permitíamos conversar pausadamente y nos entregábamos al debate. Escucho su palabra crítica, ágil en el razonamiento, conceptualmente dinámica, rica y abierta en su perspectiva, reivindicativa y siempre comprometida. Resuena incisiva cuando se tiñe de humor y de sátira. Reverbera y se expande cuando se torna sutil, rítmica, musical, poética. Su palabra rompe el continuado silencio que se ha adueñado de las tardes de invierno. Su palabra llena ese desolador vacío que nos ha quedado tras su muerte.

JOSEFA BADÍA 
SIEMPRE HABLÁBAMOS DE LA TESIS

Mira'm els ulls que cap fosca no venç. Miquel Martí i Pol

No importaba dónde nos encontráramos. Tampoco el tema de inicio de la conversación. El caso es que por una cosa u otra, siempre desembocábamos ahí. Si era un libro o una película, no importaba. De pronto, los ojos brillantes, la sonrisa como de gato, ese remolino de pelo tan cuidadamente desordenado... y jzas! la conexión. Una vez hablábamos de la compra de un sofá, sus padres acababan de comprar uno. $\mathrm{Ni}$ se te ocurra en tal lugar, me dijo, tardaron tres meses en traerlo y menos de un mes en estropearse el mecanismo. Y de ahí a la tesis. No recuerdo cómo, pero sí que pensé, caray, cómo ha estado eso de pasar de los sofás a los quinquis... No eran charlas de tutoría ni eruditas, no. Sencillamente era un tránsito natural, como quien habla de lo que ha desayunado o de la humedad en el ambiente.

Creo que no era que la tesis tuviera que ver con todo. Más bien que todo era la tesis. $\mathrm{Al}$ fin y al cabo, era una tesis sobre la vida, sobre la vida de la calle, la ciudad, sus leyendas.... Y hablarla también era vivirla. Vivir la tesis, vivir la vida, los límites se confundían, la charla fluía, el tema que era todos los temas, las ocurrencias sobrevenidas, la risa que provocaban, los afectos que se desprendían y se quedaban en el aire... La tesis era un bucle expansivo. En la puerta de la facultad, muchas veces, así de casual, así de espontáneo, tan vívido.

NURIA GIRONA FIBLA 
Una vez asalté a Tony por el pasillo del Departamento y le pregunté de sopetón, sin aviso previo, quiénes serían para él los "quinquis" o "pandilleros" de la literatura medieval. No recuerdo si contestó a esa pregunta impertinente, de profe que se las quiere dar de "graciosillo" con el estudiante de doctorado. Supongo que abrió una de sus sonrisas francas y eternas, y que con su silencio cómplice dio por más que zanjado el asunto. A preguntas necias...

Yo, sin embargo, le di varias vueltas al revoltijo de posibles marginales, delincuentes, inciviles, borrachines, juglares de medio pelo, pícaros, visionarios, mujeres de alterne, más otros tipos y tipas de malvivir... que se podrían hallar o extraer de esos textos arcaicos. Aquella misma noche soñé (yo creo que incluso llegué a ver despierto) que desfilaban ante mí, como en una de las alucinadas visiones de El Bosco, en procesión carnavalesca, mil figuras ensartadas de clérigos ebrios, ribaldos parlanchines, nobles chiflados, arciprestes amorosos, frailes fornicadores, ladrones de medio pelo, hipócritas traidores; alternando con ellos, mujeres de mala nota, juglaresas en danza, abadesas preñadas, hechiceras celestinas... Marginales todos, a cuál más escandaloso, que no había Virgen Santa que lograra meter en vereda.

Nunca le comenté a Tony mi sueño. Pero seguro que habríamos echado unas risas con la simple idea de esas imágenes esperpénticas. O habríamos discutido, más seriamente, sobre si esos outsiders execrables, parias tan frágiles como los que él estudiaba -y estimabacomo barriobajeros urbanos, no habrán existido desde antiguo, siempre apartados o excluidos desde la Ley y el Orden.

Tony habría aceptado, seguro, el reto de esa discusión. Y a mí hoy me gustaría creer en aquellos milagros de integración y perdón con fe ciega de los condenados y malditos, y pedir a un Ser supremo o a una Virgen redentora, como se hacía en aquellos gloriosos tiempos (al parecer con éxito), que recuperase y retuviese ese imposible instante de diálogo en el pasado. Y poder continuar platicando, así, de estas y de otras mil cosas en torno a las vidas al límite y a los límites de la vida, con alguien tan entrañable, sensible e inteligente como nuestro querido Tony.

RAFAEL BELTRÁN LLAVADOR. 
A lo largo de mi trayectoria docente, probablemente sean ya más de un millar las alumnas y los alumnos a los que he impartido clases de Literatura Medieval, pero solo algunas promociones se mantienen siempre vivas en la memoria, es el caso de la de 2010-2014. Y cuando veo las fotos del día de la graduación, siempre hay una sonrisa que destaca, la de mi querido Tony; sonrisa que trasluce su entusiasmo sin límites por estudiar, por aprender, por superarse, por conseguir sus objetivos; su curiosidad intelectual, versátil y polifacética, iba de la mano de su gran capacidad de trabajo, de su clara vocación filológica, de su disposición permanente a colaborar en todas las actividades y proyectos; su capacidad crítica era la base de su formación primero como alumno y, ya después, como investigador. Todas estas cualidades académicas se enaltecían más, si cabe, al estar enmarcadas en una personalidad de gran valía que nos irradiaba afecto, sensibilidad, agradecimiento, humildad, compromiso, amistad, fortaleza, empatía, generosidad. Es imposible no querer a Tony; pocas personas pueden dejar una huella tan profunda y meritoria que vaya más allá del recuerdo, su intensa y radiante luz nos ilumina a todos porque Tony, mi querido «becariet», sigue estando y estará siempre.

MARTA HARO CORTÉS 
Cuando Tony recibió una beca para trabajar en mi departamento, le di la enhorabuena con unas palabras que digo siempre en estos casos: "este es el mejor lugar del mundo para trabajar". Ahora sé que la afortunada fui yo y no él, tuve la suerte de ser su compañera. Por eso todavía creo vislumbrar su silueta haciendo fotocopias en la pecera. Ahí está Tony, pensabas, y era inevitable ir al encuentro de esa alegría radiante, ese buen humor contagioso que te hacía la vida más bonita. Debería existir una palabra para cuando nos quedamos huérfanos de un amigo, así veo a aquellos a los que Tony quiso tanto, y que tanto le querían, huérfanos, viudos, vacíos. Te echaremos mucho de menos, siempre.

VIRGINIA GONZÁLEZ 
Mi compañero de mesa:

Tony García del Río. Mi compañero de mesa. La chupa negra. Sus brazos abiertos. El piti en la entrada de la facul. La guasa. El bar(rio) y los trabajadores. La ternura en su sonrisa. Nuestra tierra. La lengua de Estellés. Mi compañero de mesa. El vaso con viñetas. Compromiso. Los cuidados. Quinquis. El amor por la literatura. Rock. La resiliencia. El tiempo que no se detiene. La suerte de haberte conocido. Mi compañero de mesa. Dignidad. Los anillos y las gafas. Justicia. De jóvenes, bandas y tribus. Bondad. Los quintos. La primavera en su sonrisa. Hombro amigo. Poeta y poesía. Este vacío. Mi compañero de mesa. El pequeño cactus. La eterna cadencia de tu alegría. Y la nostalgia. Los atardeceres suspendidos. Despacho en silencio. Imagino tu voz. "Les gotes s'acumulen com cossos sobre el parabrises". Mi compañero de mesa...

Ahora la acarician mis dedos aprendiendo a habitar tu ausencia.

ENRIQUE ANDRADE MARTÍNEZ 
A Tony lo conocí en el año 2012, recién empezado un curso lleno de huelgas y protestas contra una de las muchas leyes de educación que pretendía mermar la igualdad de oportunidades. Por supuesto, participamos en todas esas protestas, después ignoradas por la clase política. Ese curso, además, coincidimos en varias asignaturas, lo que nos ayudó a conocernos y compartir muchas conversaciones, con él y con Teresa, sobre las inquietudes habituales de los estudiantes, pero también sobre política, sindicalismo, voluntariado e inmigración. Dos años después, volvimos a coincidir en el máster. Ese año, sin duda, nuestra complicidad aumentó en la medida en que avanzaba el curso: coincidencias y confidencias en la biblioteca, por WhatsApp, correo electrónico, intercambios de ideas sobre lo que cada uno trabajaba en su TFM. Encontré en él, como estoy seguro que los demás compañeros también, a un oído atento, alguien capaz de restarle virulencia a las tormentas en un vaso de agua que nos ahogaban como estudiantes, siempre sonriente y de buen humor, de carcajada contagiosa y extraordinarias ocurrencias. Difícil será para mí olvidar esos recuerdos, como irremplazable es Tony.

Se te echa de menos, querido. 


\section{UN HOGAR EN LO DESCONOCIDO: NUESTRO AÑO CON TONY}

No fue el mejor escenario para conocernos pero, todos tan lejos de nuestro hogar, rodeados de lo desconocido y desafiante, coincidimos. Y nos elegimos acompañar.

Tony llegó a Princeton el 9 de septiembre del 2019. Era lunes. Algunas de nosotras lo habíamos conocido antes, otras ese día. Tuvimos el tiempo justo para enseñarle su residencia y cenar con él. Después de la recepción del departamento, el día 13, fuimos a Winberie's, uno de los bares locales del pueblo, un bar donde quizás no se solía escuchar la voz de Rosalía puesta con tanto volumen en los altavoces, pero bailamos y nos íbamos conociendo. En Princeton, debido a la falta de vida nocturna, terminamos en casa de Rob, que todavía no tenía sofás, y nos sentamos en el suelo, compartiendo el espacio y compartiéndonos a nosotras mismas. Tony habló de la vida, de Teresa, y de Kamchatka.

Así comenzó lo que creímos que sería nuestra cotidianidad en Princeton. Seminarios, comidas, alguna caña. Hasta que todo se giró. Desde el primer fin de semana, Tony se quejaba de un malestar de estómago permanente del que culpamos inmediatamente a la "gastronomía" estadounidense. Cuando era evidente que la comida no era la causa, puesto que sólo comía pollo a la plancha y ensalada sin aliño, achacamos las molestias al estrés. Pero cuando culpar al ambiente desafiante de Princeton era insuficiente, Tony se realiza una prueba en la consulta de la universidad. Allí descubrieron algo. No sabían qué, pero era necesario derivarlo a las urgencias del hospital. Tony ingresaba un lunes. El mismo día de la semana que había llegado al país, y el mismo día que le harían la prueba que confirmaría el final de su estancia seis semanas después.

Entonces todavía no imaginábamos qué sucedía, pero preferimos no pensar en lo peor. Decidimos cuidarle entre todas y hacer turnos para acompañarle. Aunque estaba enfermo, mantenía un optimismo contagioso. Era purificador contagiarse de su sonrisa y de sus ganas de vivir. A pesar de estar sometido a todo tipo de pruebas invasivas, a la incertidumbre y al hostigamiento inhumano de los seguros médicos, ingresado en el hospital y lejos de Valencia, Tony siempre permanecía atento a la gente que le atendía o le acompañaba, intentando mostrar calma y gratitud. Una enfermera lloró el día que le dieron el alta, porque no estaba muy habituada a pacientes así de encantadores; ella misma había destacado lo raro que era ver a una persona tan bien acompañada. Dijo que era afortunado, pero las afortunadas éramos nosotras.

Sus padres llegaron para seguir cuidándole. Merendamos para celebrar que salió del hospital, que sus padres estaban con su hijo, que iban a visitar Nueva York juntos.

Mientras, al otro lado del teléfono, estaba Teresa cuidando de Tony en la distancia, desde la escucha, el temple y la espera. 
Pero llega noviembre y, con el campus medio vacío, eran necesarias más pruebas. Todo se precipita, todo se quiebra. El día siguiente fue plomizo, urgía que se fuera.

La vuelta a España no fue sencilla; un vuelo eterno con transbordo en Lisboa que Tony hizo solo y sin demasiada energía. Lo que pasó ya nos quedaba lejos, pero volvimos a encontrarnos a la vuelta, de nuevo, unas antes, otras después. En el hospital, tomando una paella inolvidable (que nos prometimos) con Teresa y Pilar. En las videollamadas conjuntas, en los audios, en los mensajes compartidos en plena pandemia. La pandemia que desbancó los planes para reencontrarnos más veces, sumiéndonos en un estado extraño de confusión nunca antes experimentado, pero que parecía no quitarle a Tony ni la energía ni las ganas, como refleja su lema: "I només quan hi som és quan encara ho podem tot enmig de tanta foscor”. Qué de cosas ocurrieron de un otoño a otro.

No hay forma buena de cerrar este texto. Ojalá no tuviésemos que estar escribiéndolo un año después de conocerte.

Tony, t'estimem. Gràcies per formar part sempre de la nostra llar imaginada.

AlDARA, BERTA, RoB, SOFÍA 